\title{
Study and Redefining Beneficiary Participation in Process Of House Design
}

\author{
Morteza Monshizadeh ${ }^{1 . a}$, Sr Dr Norngainy Mohd Tawil ${ }^{2}$ Maria Khosravi ${ }^{3}$ \\ ${ }^{1}$ Ph.D. Student Universiti Kebangsaan Malaysia, Architecture Department \\ ${ }^{2}$ Deputy Director of CESMED Universiti Kebangsaan Malaysia \\ ${ }^{3}$ Ph.D. Student Universiti Kebangsaan Malaysia, Architecture Department
}

\begin{abstract}
Since housing has a special place in human life and his physical, psychological and interactions, so in addition the unity of humans, multiplicity and diversity of them must be considered. This possible only by beneficiary participation in the design process, but because society has different economic and social texture and classes; and settling suit because of the time and place of special indexes are entitled, so prepare a comprehensive model includes the testimony and circumstances; identify factors influencing participation optimum need to selection population and certain species of private construction. Standard tool to study topic does not exist, so in order to produce tools using qualitative research methods; interpretation - historical correlation to extract components and variables and their effects on each other and enjoyed target table Content consisting of four domains of general knowledge specialized knowledge of participation - participation mechanisms and factors influencing participation achieved. Extracted factors are: the initial formation of partnership - partnership executive process - the role of participant optimal participation; by study and analyze the theoretical model. Due to history and social aspects; cultural participation in Shiraz; promote scientific and participatory approach designed to make operating housing; bed and new horizons of development of facilities and areas in the design of residential environment created and due consultation and decision making in addition to beneficiary participation to promote optimum utility of space; mutual flexibility and utilization of space; increase fixation and motivation will lead beneficiary reside" and the main question: "how is the model of scientific position optimal participation planning instrument in private housing in the city of Shiraz, in the process of design, implementation and use".
\end{abstract}

\section{General participatory concepts and approaches}

Participation is included by different interpretations from various school and view, and it is result from consideration toward beneficiary and lower classes of people due to paying attention to intrinsic nobility and nature, and in this regard, by Consider to theorists concerns about functional aspects, the outcome and results, effective factors, the activity and action, its aspects of the instrumental and purpose is very different.

There are some belief in all attitudes and schools about the existence of prerequisites and situations in formation as well as in step by step way that it can be different according to interpretations and conditions. But the common point is that cultural and social conditions are required in forming participation. If it is necessary to take advantage from the people's perspective, Society should already have such potential and also ready to training and institutionalizing in this field, until the conditions of

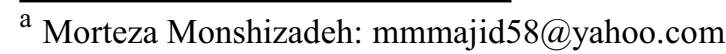

provision and facilitating in participation can be provided.

\subsection{Literal meaning of participation}

Participation is equivalent of English term "cooperation" that is the root of the word "Part" means the component and section, and also it means " sharing in something or taking part of that" (Rezai, 2002). In the Oxford Dictionary, it is defined a real of Interaction or participating and sharing (Ghaffari, 2001). "Apparently, Perhaps, a consensus and convergence in the meaning of participation is implied, But because this term is observers of the rate and method in presenting ideas and methods, activities, projects, programs and decision-making of people, so it can be very controversial" (Qubadi, 2002).

\subsection{Descriptive meaning of participation}

Participation is a kind of solidarity and belonging and collective effort among individuals in a society in other to achieve a social justice system (Sepehri, 1993) 
and "its infrastructure is placed in the process of need assessment of decision-making, planning, implementation, review, evaluation, common benefit of people" (Sarkezi, 2002). (Mclagan, 1955) "Describing the participation dependence on the various factors such as social, economic and political, So that we faced with various interpretations and inferences sometimes with contradictory and opposition levels and categories" (Islami, 1999).

\subsection{Participatory approaches from the perspective of individuals and organizations}

Since participation in many fields that related to human problems and is able to be investigated and used, therefore people who has various expertise, goals and specific approaches, with different interpretations and definitions, have been used (Table $1)$.

Table 1. Comparison of approaches derived from individuals and organizational theories about the issue of the participation.

\begin{tabular}{|c|c|}
\hline Biro; 1996 & $\begin{array}{l}\text { Voluntary activities in the State } \\
\text { - City - the village and the } \\
\text { former of social life and } \\
\text { politics }\end{array}$ \\
\hline Babai; 1997 & $\begin{array}{l}\text { Including the people in the } \\
\text { organization - decision-making } \\
\text { and interventions - equal and } \\
\text { same opinion. }\end{array}$ \\
\hline Ghobadi: 2002 & $\begin{array}{l}\text { Collective use - having natural } \\
\text { and internal root and result } \\
\text { from cooperation among } \\
\text { human and relate to rate of } \\
\text { people benefit }\end{array}$ \\
\hline Tokoyol:2005 & $\begin{array}{l}\text { Human right - democracy and } \\
\text { growth and Promotion of } \\
\text { citizenship- Culture Promotion } \\
\text { in Discipline and awareness of } \\
\text { the issue of human rights and } \\
\text { government }\end{array}$ \\
\hline $\begin{array}{l}\text { Habibi-razavi: } \\
2005\end{array}$ & $\begin{array}{l}\text { Public participating in policy } \\
\text { and } \\
\text { formulation }\end{array}$ \\
\hline Tabrizi: 1991 & $\begin{array}{l}\text { Belongs - profit - a share in } \\
\text { something - participating in a } \\
\text { group }\end{array}$ \\
\hline $\begin{array}{l}\text { Habbi- jal elahi: } \\
2003\end{array}$ & $\begin{array}{l}\text { using collective resources in } \\
\text { order to participating people - } \\
\text { the relationship between effort } \\
\text { and resources to the } \\
\text { relationship between the results } \\
\text { and efforts }\end{array}$ \\
\hline Okeli: 2003 & $\begin{array}{l}\text { Sensitization of people and } \\
\text { increase the acceptance and } \\
\text { ability to respond to } \\
\text { development - involving people } \\
\text { in the decision - }\end{array}$ \\
\hline
\end{tabular}

\begin{tabular}{|c|c|}
\hline & $\begin{array}{l}\text { Implementation - Evaluation } \\
\text { Program }\end{array}$ \\
\hline Alen,piruft: 2002 & $\begin{array}{l}\text { Consultation before the } \\
\text { decision - personal comments } \\
\text { and actions of administrative } \\
\text { administrators decisions caring }\end{array}$ \\
\hline Kurt depfer:2002 & $\begin{array}{l}\text { Ratio of practical interventions } \\
\text { that is required and amount of } \\
\text { interference in the activities of } \\
\text { the group }\end{array}$ \\
\hline Salima: 2002 & $\begin{array}{l}\text { Intervention and control of } \\
\text { people for better life - } \\
\text { reflection of values system are } \\
\text { sacred and important }\end{array}$ \\
\hline Qafari: 2001 & $\begin{array}{l}\text { Mutual Interaction to form a } \\
\text { foundation of social life - } \\
\text { comprehensive and empower } \\
\text { people based on three values } 1 \\
\text { - shared by people in authority } \\
\text { 2. Voting } 3 \text {. Open the } \\
\text { opportunities to the lower } \\
\text { categories and classes }\end{array}$ \\
\hline Tosi: 1991 & $\begin{array}{l}\text { Mental and emotional } \\
\text { involvement of people to help } \\
\text { each other in achieving the } \\
\text { goals of the group and the } \\
\text { division of responsibilities }\end{array}$ \\
\hline Mir Musavi: 1996 & $\begin{array}{l}\text { Conflicting and individuals } \\
\text { activities of affecting for a } \\
\text { particular purpose }\end{array}$ \\
\hline Burki: 2001 & $\begin{array}{l}\text { The relationship between } \\
\text { essence of man and sustainable } \\
\text { development and efforts to } \\
\text { eliminate the poverty and } \\
\text { promote development and } \\
\text { exploitation }\end{array}$ \\
\hline $\begin{array}{ll}\text { Alavi } & \text { Tabara; } \\
2003 & \end{array}$ & $\begin{array}{l}\text { Social behavior, consciously } \\
\text { and voluntarily, and intend to } \\
\text { make individual or collective } \\
\text { interests - mental desire to do } \\
\text { certain tensions }\end{array}$ \\
\hline (F.A.O) & $\begin{array}{l}\text { Involving people in the lower } \\
\text { classes in program } \\
\text { development, and organize } \\
\text { them in for public participation } \\
\text { programs }\end{array}$ \\
\hline $\begin{array}{l}\text { United Nations } \\
\text { Research } \\
\text { Institute(UNRISD) }\end{array}$ & $\begin{array}{l}\text { Organized efforts to increase } \\
\text { control interests and regulatory } \\
\text { agencies by some groups and } \\
\text { organizations that have been } \\
\text { deprived }\end{array}$ \\
\hline World Bank & $\begin{array}{l}\text { The division of responsibilities } \\
\text { for program development } \\
\text { decisions and resources } \\
\text { associated with the program }\end{array}$ \\
\hline $\begin{array}{l}\text { International } \\
\text { Labour } \\
\text { Organization } \\
\text { (I.l.o) }\end{array}$ & $\begin{array}{l}\text { The proportion of individuals } \\
\text { or organized groups of active } \\
\text { population economically and } \\
\text { socially }\end{array}$ \\
\hline
\end{tabular}




\section{Types of participation in terms of process and purpose in the development program}

Pretty (1955) argues that, if it was accepted that there is always some degree of participation in human societies, then it is useful to know that these contributions from what types can be our participation in our society which one is presented of the cases above. Of course, other forms of participation may also be introduced in other classification. Another important point is that each of the following participation has specific social effects on its own group or society (Ghobadi, 2002).

\subsection{Self - mobility participation}

In this type of participation, people operate without dependence on external organizations in their activities. But there are controls on the using resources. If governments and NGOs can create a required framework to support these types of activities, self-mobility may develop. This type of participation also called "innovative self - mobility".

\subsection{Interactive participation}

In this type of participation, public participation activities develop interaction patterns and information. These activities strengthen local organizations. The right is considered for community members in this participation model and the purpose of paying them not only to achieve project goals. Here participation is multi-dimensional process that can be considered from different aspects and also its learning process is structural. Acceptance of regional decisions by Group members determine how available resources are used, In this case, individuals have important factors for maintaining their achievements.

\subsection{Functional participation}

In this model, participation is known as the process of achieving goals and cost reduction. Individuals are organized in order to achieve pre-determined targets of the participation. This relationship may be interactive. It may also include decisions or their related processes. But this process only occurs when major decisions (external) are adopted by external institutions. In this situation, the local individuals are still affected by external goals (which are not involved in its formulation).

\subsection{Participation for financial incentives}

In this participation model is done for financial incentives. And here individuals expect that their participation targets is specified, And In this model problems are defined by external organizations, And the process of data collection is done the same way, Control of the process is also similarly under the supervision of external organizations. In such process is not seen participatory consultation in the decisionmaking.

\subsection{Passive participation}

In this type, public participation is based on previous decisions. This is done without any regard of people responses, based on unilateral notification of managers. Here, the information is shared from the external professionals.

\subsection{Strategic participation}

In this participation model can be seen, representatives of people are actually present in formal organization, but they have not special power

\section{Types of participation in terms of function}

In this field, there are various types of participation, special platform encourage was considered for group participation of all people. Hence "participation from different points of view can be classified as follows:" (Table 2).

\subsection{Aspect of amount of people's participation}

Aspect of about the extensive involvement of people in participation decision is divided into two types:

a) Basic participation: This method participation represents relatively comprehensive participation of complete social groups. Each application stages including need assessment and decision-making for planning, implementation and evaluation is done by the community groups of interest.

b) Marginal participation: In this method, the participation used to implement some applications and specific purposes. In fact, the marginal participation is a onedimensional participation. For example, in the economy, participation in the investment projects, by the people, is one kind of marginal participation.

\subsection{Participation in terms of territory}

This has three categories on the basis of participation importance in any aspect of group life:

1) Political participation: Is the participation of social groups in the programs and political activities and engaging people in the administration of the society. 
2) Social participation: Includes social group's participation in social and cultural programs and activities.

3) Economic and financial participation: Includes participation in programs of social groups and economic activities and emphasizes on the financial participation.

\subsection{The aspect of people's involvement quality}

Based on how and the way people play a role in the programs:

a) Direct participation: In this method people are directly involved in the decision-making of programs and activities.

b) Indirect participation: In this method through their representatives are involved in decisionmaking.

\subsection{The aspect of implementation levels}

Based on implementation levels requiring people's involvement in activities and programs:

a) Participation in rural levels: Rural people can participate in special programs and activities in their rural area.

b) Participation in regional levels: People can participate in programs and activities of regional and provincial areas.

c) Participation at the national levels: At the national level all people can participate in programs and national plans.

\subsection{The aspect of democracy}

The degree and range of participation democracy that should be considered:

a. Compulsory participation: People or social groups will participate in the programs and activities of non-voluntary and forced.

b. Optional participation: People or social groups will participate as voluntary and interest in the programs and activities.

\subsection{The aspect of profit}

In terms of what individual or group will directly obtain benefits, advantages and results of Participation:

a) Self-help: The person or group who is helped in an activity (participation), in the activity (if necessary) will help one previous participation mutually (participation).

b) Assistances: in the assistances process, all people and social group participate in decisions making, plan implements and activity and all of them has shared profit of participation. Assistance is kind of public participation.

c) Helping to other: participated person or group helps to other person or group (participation in public profits and welfare affairs).

Table 2. Participation for Financial Incentives (Farhang and Taavon 1999).

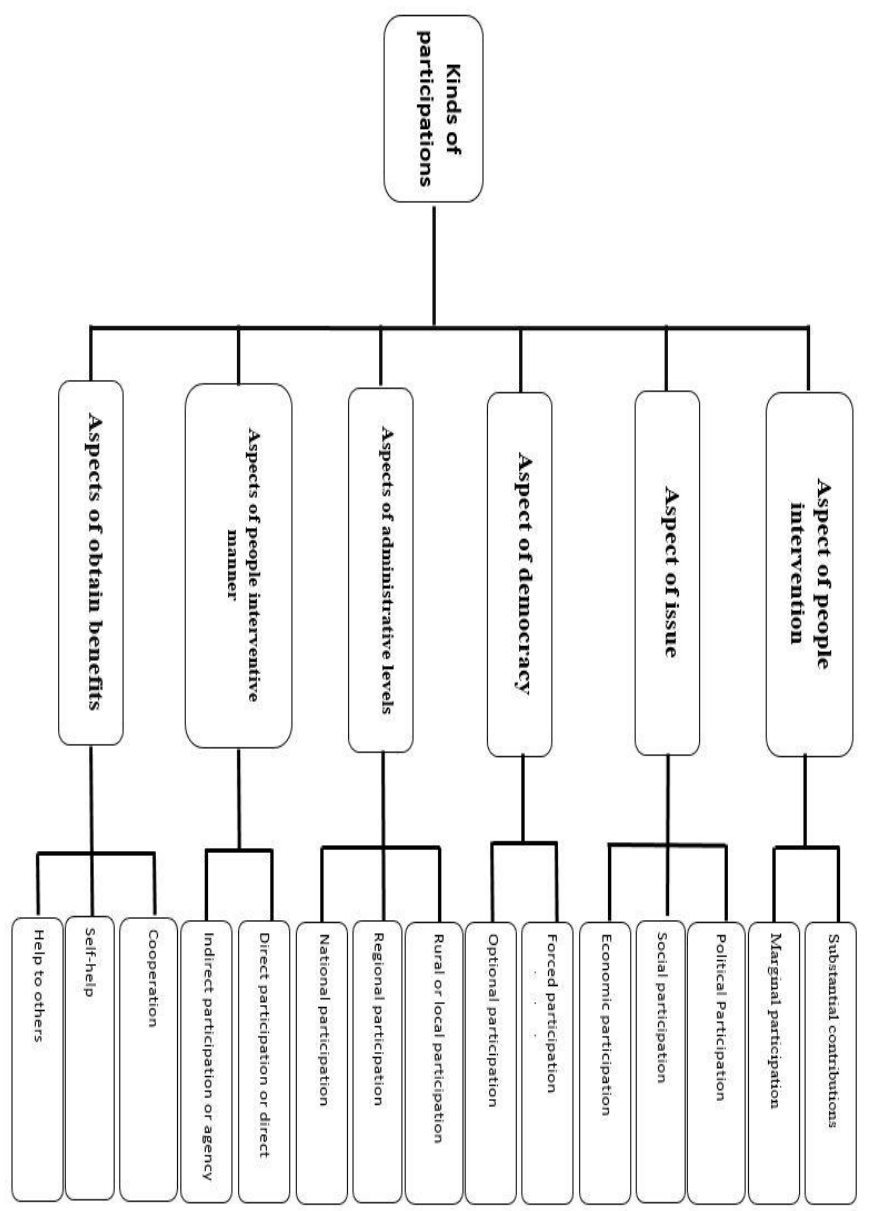

\section{Beneficiary participation process based on human needs (adaptation of human needs and participation model)}

\subsection{Hierarchy of needs}

Maslow introduced the famous hierarchy of needs theory in 1943. He thinks that motivation is function of the five basic needs, including physiological, safety, social, esteem, and self-actualization, and these needs can be explained in a hierarchy. In other words, he believes that the emergence of human needs has developed in a step-by-step way in a way that selfactualization need flourish. "If we accept this hierarchy of needs, the question is that the person whose social needs prevalent, for example, if a certain degree of participation works better in such case? In other words, if there is a relationship between 
hierarchy of needs and degrees of participation anymore? The answer to this question lies partly in the theory of situational leadership." (Figure 1)

Figure 1. Maslow's hierarchy of needs theory (Rahnavard, 2006, 117)

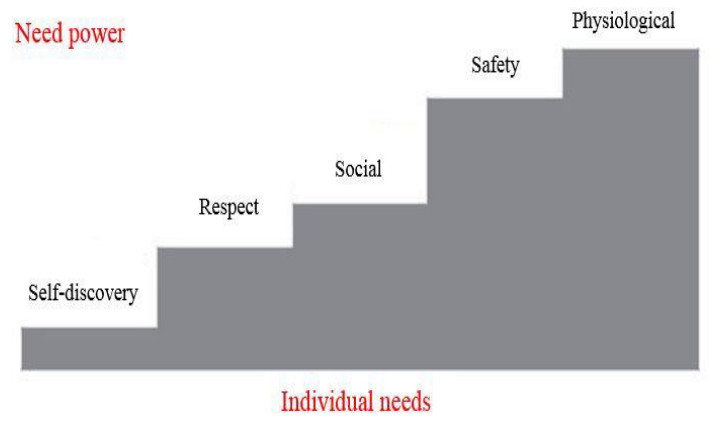

\subsection{Degrees of participation and hierarchy of needs}

Situational leadership theory (Hersey, 1988) between leadership styles and hierarchy of needs establishes one by one relationship. As shown in Diagram 2, collaborative style of working fits those who are motivated by social needs and respect, submission style fits those who mostly need self-discovery, while command and incentive styles fit those who are motivated by basic needs. If we look more closely into submission style, we can say that this power or authority is given for an individual or a group. In the latter case, semi-autonomous or autonomous groups are formed that shows complete degree participation.

Therefore, if we interpret command and incentive styles as non-participation, it should be said the theory of situational leadership forms one by one relationship between degrees of participation (non-participation, partial participation and full participation) and hierarchy of needs." Davis and Veniostrum (1989) state that there is evidence that many of people don't want to be hurt by participation and this question is raised out that we should steer them towards participation just for this reason that we think participation is good for them?

Figure 2. The relationship between degree of participation and needs based on situational leadership theory (Rahnavard, 2006)
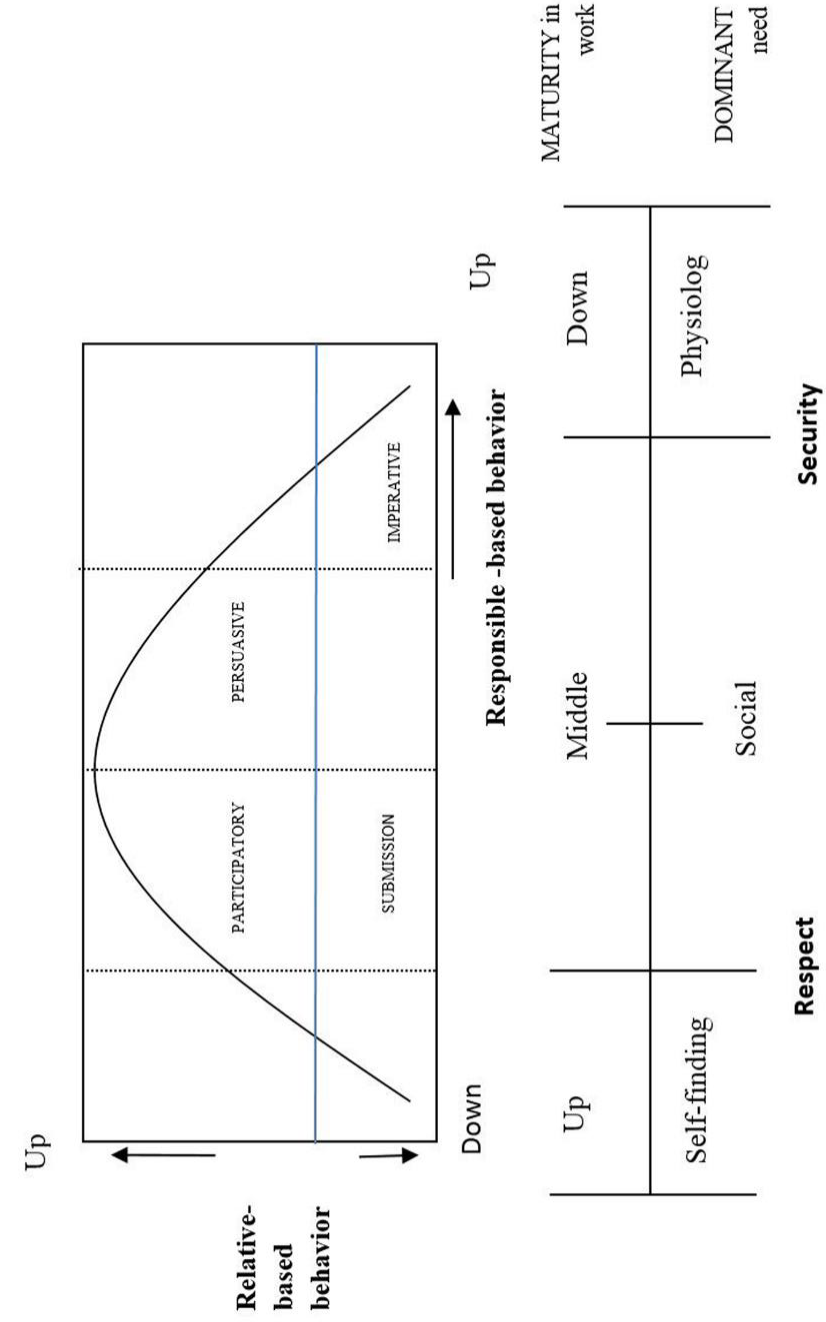

\subsection{Under- participation, over- participation, degree of satisfaction}

If you look at the reality from another angle, it may be argued that people whose basic needs are prevalent do not tend to participate. In other words, we can relate the unwillingness of people to participation with the type of prevalent needs. In this case, this question can be raised out that if there is one by one relationship between degree of participation and hierarchy of needs of human. The main reason for such a question arises from the fact that if there is one by one relationship between the needs and degrees of participation, the implementation of a specific model of participation in an organization and generalizing it to all people may result in "under-participation" or upper-participation" phenomenon. Davis and Veniostrum (1989) believe that some people demand more participation than other people. However, the main problem is that in both cases of "under-participation" and upperparticipation" people show low level of satisfaction compared with situations in which their participation 
is based on their needs. This relationship is shown in diagram 3. This model also verifies this point that there is significant relationship between the needs of human and degree, and their conformity creates the maximum satisfaction.

Figure 3. conformity of needs with participation (Rahnavard, 2006).

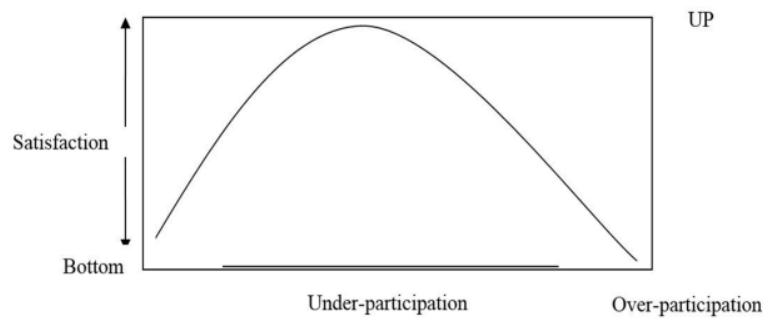

\subsection{One by one relationship}

In the discussion about management, situational leadership theory (Hersey and Blanchard, 1988) and compliance of needs with participation (Davis \& Veniostrum, 1989, 14) it is implicitly verified that "one of the requirements for effective participatory management is the compliance between needs and degree of participation." In spite of the relationships that have been established between the needs and levels of participation in such normative models, the question is still that which degree of participation conforms with prevalent need in an individual and if field studies confirms such relationship? Based on such models, this hypothesis is proposed that people with prevalent basic needs respond better to low degrees of participation, and people with secondary needs respond better to over-participation. In other words, by establishing one by one relationship between prevalent need and specified degree of participation, we can increase the achievement of participatory programs provided that other needed factors to be provided to achieve such programs (Figure 4).

Figure 4. Relationship between prevalent need and degree of participation (Rahnavard, 2000).

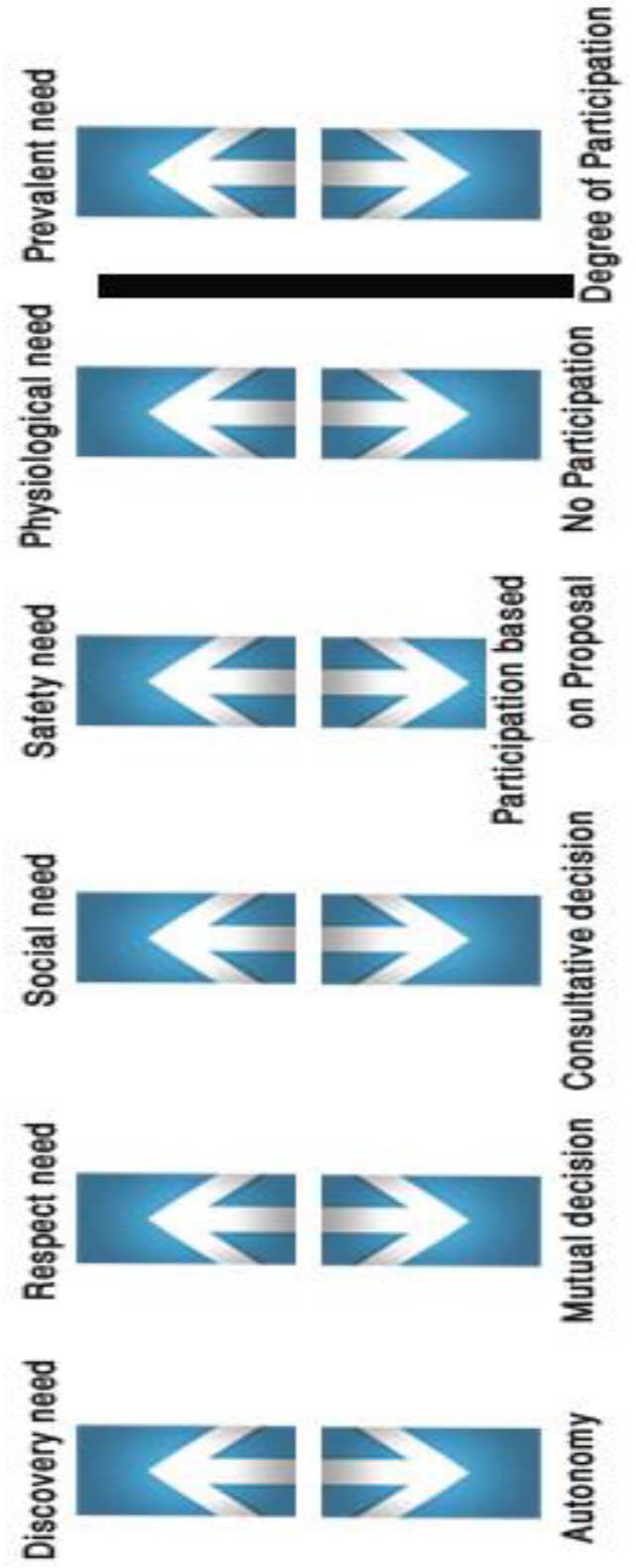

\section{5 participation in citizenship regulations and urban designing}

In contemporary world, various points of view are made in one of the highest citizenship level (urban designing and planning by people) along with obtained sophistications in cities that mostly tries to determine a boundary between participation and non-participation besides participation functional aspects and consider hierarchy to facilitate achievement to project studies by professional architecture designing.

\subsection{Participation process from politics and culture to urban and citizenship field}

Roots of participation meaning can be searched in old Greece cities-government. In present time, after new- 
born evolutions and passing middle centuries, simultaneous to the most important role of people in society, participation in political and social era by rewarding polling right and equal right for citizens and right of establishing civil groups and committee have been appeared. Now, citizens' participation in social and political affairs is accepted as a principle in all developed and many developing countries. It takes a long time to change meaning of participation from culture and politics field to planning field. Citizens' participation in related affairs to urban and urbanizing was first shaped at the end of 1950s and beginning of 1960 in US. In this period, various rules were designated based on citizens' participation that changes nature of urban decision-making "participation conception in the middle off 1960s was proposed in England, then other democratic countries have followed it (Oosthuizen 1998).

\subsection{Urban participation of action with various dimension}

As it was mentioned, participation as a human action needs certain conditions and facilities. There are 4 interests in human as action fields. In other words, "studies in urban management and citizens role indicates that people are influenced by their interests in urban management field and show different actions to get to their purposes (Mozayyani, 1996) (Table 3).

a. Cognitive Interest: it needs to have intellectual and emotional cognition from generalities and details- presentation in empirical sciences, philosophy and mysticism.

b. Material Interest: It provides interest to imagine environment by possibility to conquer adapted to environment.

c. Communicational Interest: It makes reciprocal friendly connection (to be one or we)- understanding intra-mental relationships- exchange

d. Security Interest: Life security-financial security-intellectual security- mass security. (Chelbi, 1996)

Four actions are defined as following based on the mentioned interests:

a. Value action: tools maybe revised, but purposes won't be revised because they are based on principles and values.

b. Tool action: it is done to calculate the relationship between tool and purpose. Social actor may change tools of arriving to purposes to facilitate his work and change mind based on conditions and facilities to get necessary tools in purpose.

c. Traditional (mechanical) action: this action is based on mere imitation and unconscious obey from continuous traditions.

d. Emotional (sensational and nonintellectual) action: "humanistic emotional and sensational life is not disciplinable and predictable and it is done without calculation of tool and purpose (Bushriyeh, 1995). Finally we can name four scopes appropriate to interests and mentioned actions: (social sub-systems)

e. Culture field: cognitive interests and value actions

f. Economics field: material interests and tool actions

g. Communication filed: communicative interests ad traditional action

h. politics field: security interests and emotional actions

Table 3. Humanistic actions, reference (Alavitabar2003).

\begin{tabular}{|l|l|l|l|}
\hline $\begin{array}{l}\text { Four general and main } \\
\text { interests: }\end{array}$ & Four forms of actions & Four main scopes (construction) \\
\hline Cognitive interest & Value action & Tool action & Culture field \\
Material interest & & Traditional action & Economics field \\
Communicative interest & Communication field \\
Security interest & Emotional and sensational action & & Politics field \\
\hline
\end{tabular}

According to the nature of each social sub-system, (political, economic, cultural, and communicative), it can be claimed that the main role to make intention to participation is cultural and communicative system duties. In other words, the nature of these 2 systems determines how much people are interested to participate in determining policies and their administrators act actively. But what makes possibility for this participation and determine a certain framework for it are 2 cultural and economic systems. Legal, institutional, facilities and economic abilities in participation field are shaped by being influenced of these 2 sub-systems, (Alavitabar, 2003).

\section{Participation architecture designing and status of beneficiary and designer}

\subsection{Participation in designing and planning according to theorists' point of view}

The importance and role of architectures and planners not only for professional responsibility in final decision-making and its role in development process of relationships among participators in a design, but also for the important nature of planning and architecture issue, has status that should claim architecture is obliged to find proper and acceptable response for conditions (environment, utilization, beneficiary etc.) among relatively contradicted economic, technical, social, and functional issues (Giancarlo, 2005). He shaped "manner, amount, pattern, comparison and various interpretations from various theories designing under various titles:" (Kamelnia, 2008). 
In comparatives, besides explaining some of theorists' ideas, some contradictions become clear among them which are one and the most important unsolvable affairs.

John Turner believes "participation is not necessarily said to build a structure by inefficient-valid people with a few tools or negligible materials. A main issue is control and power of decision-making. (Hamedi, 1991)

Hueli (2004) used expression of "participatory architecture" as a designing system to develop users' wills.

"Habrakan" knows participation as a deniable issue, he know creativity as an individual action while designing is among people according to his idea. (Eslami, 1998)

Sanouf (2000) believes that "physical environment is designed by a few people but many people use it." Janson (1979) explored participation according to various points of view.

Participation is a tool to get necessary information (by addresses' point of view) and also a tool along with political changes, as though; the range of this effectiveness can lead to fully individual wills (even anarchistic points of view) or socialistic points of view.

- Participation as an attractor of others beliefs can be efficient for experts.

- Participation can play a fully nostalgic role, because when decision-making goes to its pervasive aspect, gets more emotional and nostalgic sense.

- Participation as a theoretical design includes points of view which believe experts in designing field should interrupt users and other people in design. In this regard, experts should help people to get to their real wills.

- Participation as a developer of mass behavior developer communicates more with participators.

- Participation can teach people by participatory process.

- Participation as an aesthetics theory believes to give fresh energy to architecture by interrupting people so their aesthetic selections and talents.

\subsection{Participation in architecture design approach}

"Salama" (1995) in book "new intentions in architecture training (based on Brad Bent idea), knows traditional approach of design include pragmatic design, Iconic design, and analogical design (Heth, 1984). He believes that in 2 recent decades, modern architecture approaches have been shaped including systematic design, pattern language, and participatory design. (Table 3) (Table 4) In 1970s, one of the most important issues in participation part in design is nontransparency of communicative mechanisms among specialized and non-specialized. Therefore, many of participatory designs are guided in one-way from experts and their ideas have been imposed in incomprehensible diagrams and plants for users. By starting design methods and processes in these years and also systemic attitude to architecture process, a form of communication was made among these ideas, computer programs and participatory issues were appeared.

"By more clarifying design process, computers have made vast field of communications participatory to help design process to make a building user to participate computer design process who wasn't involved in past. (Till, 2005) "Maybe definition of a design process and its various steps are not seemed very simple and there are many disagreements for its sophistication in this field, but design processes can be determined by theorists' points of view with scientific confrontation of this issue and exploring various samples. Design process patterns include 2 groups." (Mahmudi, 2005).Systematic pattern and environment recognition pattern has 2 public approaches in systematic pattern: Stage-phase approach that design process has been made from various steps coming following each other and rational approach that divides it to smaller parts to solve design problem. Environment knowing pattern is mostly related to human, environment, and balanced thought in architecture design.

Table 4. Models and approaches of design (Kamelnia, 2008, 94).

\begin{tabular}{|c|c|c|c|}
\hline \multicolumn{4}{|c|}{ Designs models \& Approaches } \\
\hline \multirow{3}{*}{\multicolumn{2}{|c|}{ Designs Model }} & \multirow{2}{*}{\multicolumn{2}{|c|}{$\begin{array}{l}\text { Intuitive Model } \\
\text { Rational Model }\end{array}$}} \\
\hline & & & \\
\hline & & \multicolumn{2}{|c|}{ Participatory Model } \\
\hline \multirow{7}{*}{$\begin{array}{l}\text { Design } \\
\text { Approache } \\
\text { s }\end{array}$} & \multirow{4}{*}{$\begin{array}{l}\text { Traditional } \\
\text { Approache } \\
\text { S (Brad } \\
\text { Bent) }\end{array}$} & \multicolumn{2}{|c|}{ Pragmatic Design } \\
\hline & & \multicolumn{2}{|c|}{ Iconic Design } \\
\hline & & \multicolumn{2}{|c|}{ Analogical Design } \\
\hline & & \multicolumn{2}{|c|}{ Canonic Design } \\
\hline & \multirow{3}{*}{$\begin{array}{l}\text { New } \\
\text { Approache } \\
\text { s (Salama) } \\
\end{array}$} & \multicolumn{2}{|c|}{ Systematic design } \\
\hline & & \multicolumn{2}{|c|}{ Pattern language } \\
\hline & & \multicolumn{2}{|c|}{ Participatory design } \\
\hline \multirow{4}{*}{\multicolumn{2}{|c|}{$\begin{array}{l}\text { Design process pattern } \\
\text { (Mahmudi) }\end{array}$}} & \multirow[t]{2}{*}{ systematic } & $\begin{array}{l}\text { Stage- } \\
\text { phase }\end{array}$ \\
\hline & & & Rational \\
\hline & & \multirow[b]{2}{*}{$\begin{array}{l}\text { Environmen } \\
\mathrm{t}\end{array}$} & Man-Env. \\
\hline & & & $\begin{array}{l}\text { Interactiv } \\
\mathrm{e}\end{array}$ \\
\hline
\end{tabular}

Table 5. Design approaches include systematic design, pattern language, and participatory design.

\begin{tabular}{|l|l|l|l|l|}
\hline $\begin{array}{l}\text { Deign } \\
\text { approa } \\
\text { ches }\end{array}$ & Fields & $\begin{array}{l}\text { Fields } \\
\text { sub- } \\
\text { groups }\end{array}$ & $\begin{array}{l}\text { Particip } \\
\text { atory } \\
\text { approac } \\
\text { h title }\end{array}$ & $\begin{array}{l}\text { Approa } \\
\text { ch sub- } \\
\text { sets }\end{array}$ \\
\hline $\begin{array}{l}\text { Systema } \\
\text { tic } \\
\text { design }\end{array}$ & Scopes & $\begin{array}{l}\text { Sub } \\
\text { direction } \\
\text { s of } \\
\text { scope }\end{array}$ & $\begin{array}{l}\text { Title of } \\
\text { P.A }\end{array}$ & $\begin{array}{l}\text { Sub } \\
\text { directio } \\
\text { ns } \\
\text { approac } \\
\text { h }\end{array}$ \\
\hline
\end{tabular}




\begin{tabular}{|c|c|c|c|c|}
\hline $\begin{array}{l}\text { Pattern } \\
\text { languag } \\
\text { e }\end{array}$ & & & & \\
\hline \multirow[t]{4}{*}{$\begin{array}{l}\text { Particip } \\
\text { atory } \\
\text { design }\end{array}$} & $\begin{array}{l}\text { Political } \\
\text { sciences }\end{array}$ & 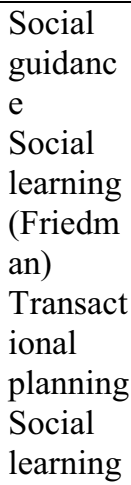 & $\begin{array}{l}\text { Advocac } \\
\text { y } \\
\text { planning }\end{array}$ & $\begin{array}{l}\text { Social } \\
\text { plannin } \\
\text { g } \\
\text { Particip } \\
\text { atory } \\
\text { plannin } \\
\text { g }\end{array}$ \\
\hline & \multirow[t]{2}{*}{$\begin{array}{l}\text { Social } \\
\text { organiza } \\
\text { tion }\end{array}$} & $\begin{array}{l}\text { Durkhei } \\
\mathrm{m} \\
\text { theory }\end{array}$ & \multirow[t]{2}{*}{$\begin{array}{l}\text { Social } \\
\text { architect } \\
\text { ure }\end{array}$} & \multirow[t]{2}{*}{$\begin{array}{l}\text { Social } \\
\text { plannin } \\
\mathrm{g}\end{array}$} \\
\hline & & $\begin{array}{l}\text { Weber } \\
\text { theory }\end{array}$ & & \\
\hline & $\begin{array}{l}\text { Environ } \\
\text { ment } \\
\text { psycholo } \\
\text { gical } \\
\text { studies }\end{array}$ & $\begin{array}{l}\text { Percepti } \\
\text { ons } \\
\text { psychol } \\
\text { ogy } \\
\text { (Bruwic } \\
\text { k } \\
\text { Gibson) }\end{array}$ & $\begin{array}{l}\text { Commun } \\
\text { ity } \\
\text { architect } \\
\text { ure }\end{array}$ & $\begin{array}{l}\text { Particip } \\
\text { atory } \\
\text { architec } \\
\text { ture } \\
\text { Social } \\
\text { architec } \\
\text { ture }\end{array}$ \\
\hline
\end{tabular}

\subsection{Empirical modelling}

Empirical modeling (resulting from library and field research and experiences): The phenomenon of participation in housing design can bring reasonable achievement, if we identify its effective and basic factors and organize its process under a coherent structure (system). The mentioned system has components that, according to nature of the subject, involve all of social affairs (human and cultural) and economics and politics affairs, and on the other hand, we cannot ignore, the role of the religious ideas of the designer and also family and individual characteristics of beneficiary, in this process, in a way that illustration and compilation of above systematic method is beyond the ability of architectural designer and this highlights the role of other experts as well.

This process, in macro scale, can be considered as a unilateral movement, from prerequisites of participation (its contexts) to the participation itself, and the feedback (a movement which is complementary for it or opposite to it) will be the impact of the final product on the process and its impact on the beginning.

Contexts are the initiators of participation and their objective is true participation and true participation is a tool to the ultimate goal that is a worthy housing design, which can be described as a product and at the end by formation of this process, due to its useful mentality and feedbacks, promotion and enhancement of cooperative culture will emerge and its effects on this process will be doubled. With this attitude, the contexts in the role of the independent variable will serve the dependent variable, which is true participation, but as the final objective is housing design, by changing the role of true participation (which itself is now a tool in the service of the ultimate objective) to the mediator variable, worthy housing will be considered as the dependent variable. Diagram 5 indicates that these series can continue due to the different objectives of different researches and by defining new objectives, roles of variables can change as well.

Figure 5. Factors contributing in housing design process and the role of variables.

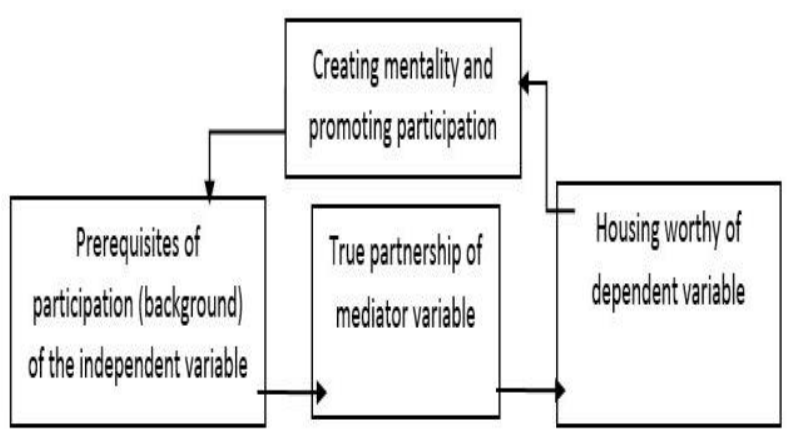

Based on field studies and professional experiences and exchanging opinions with experts, all of effective factors in the above diagrams can be modeled -as Model (1)-, in an appropriate and inclusive process, which in addition to showing the hierarchy between these factors, considers all the conditions involved in this process and considers their impacts as well. 
Figure 6. Model (1): experimental model of Cooperative design process.

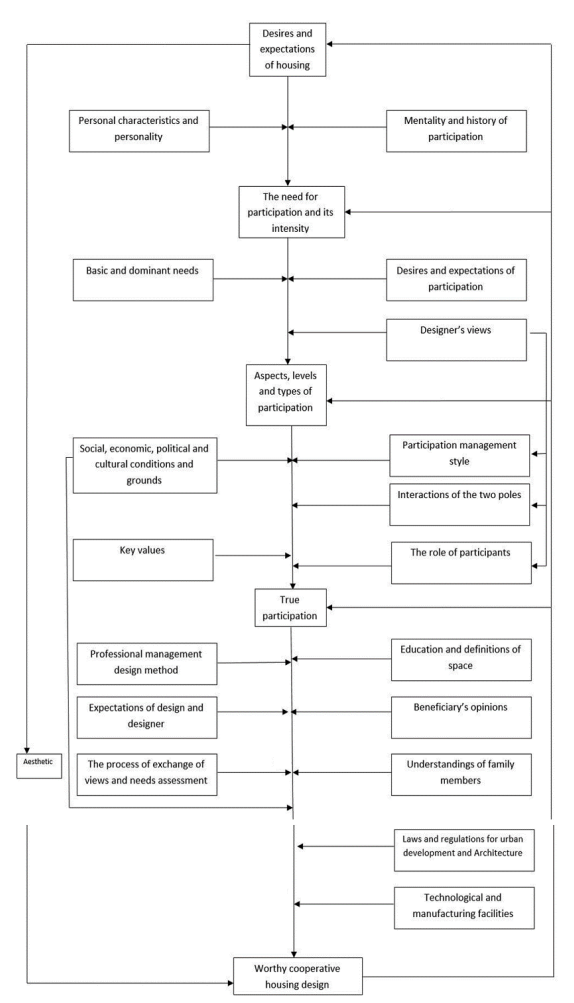

\section{Extraction of variables (back ground for closed question- answer)}

Variables are extracted after recognition the goals and evaluation of them that is the base for closed (pack) questions. These variables with notice to goals are:

a. Familiarity of people with partnership

b. Familiarity of people with legal right

c. Familiarity of beneficiary with design capabilities

- Familiarity of beneficiary with contemporary facilities in design and construction

- Familiarity of beneficiary with the possibility of presenting and visualization of design

d. The method of accepting new knowledge by the beneficiary

e. The tendency of the beneficiary to involve others

f. The method of requesting by beneficiary

g. Effects of psychological tendencies in the design results

h. The desire and need of the beneficiary in relation to the designer's attitude

i. Barriers to participation

j. Beliefs (quiddity)

- Values (what should be done)

- Norms (what is done)

k. Mood and ethnic features of beneficiary and the effects on participation

Factors Affecting Participation

- Mood and ethnic features of beneficiary and the effects on the design

\section{Research method}

In achieving the goals of the research, the main research methods, field and instrumental research methods are used to success of the program. Main methods consist of: Survey Method, Comparative Causal Research Method (Post-Events), Instrumental and Field Research Method, and Performance and Results of Instrumental Methods Used in Library and Field Studies.

"Members of a real or imagined set from people, events or objects, which we tend to extend findings of our research to them, is called statistical population" (Gall et al, 1996, p. 19).

In this research, the study population consists of individuals, in Shiraz city, who have referred to the architectural design office to design their own housing and this is called private building.

In this study was used the multi-stage cluster sampling method, because there is the different stages in building and validating research tools. In this way such as clustering sampling the measuring unit is not single but is a group of individuals that is shaped naturally as a group. When we use clustering sampling the choosing of people is more acceptably possible and easier than choosing individuals from a society. In clustering sampling when was selected randomly, you can continue sampling in the area (Delavar, 1995, 23) as follow:

1. To meet the terms of beneficiaries based on the economic situation, funds, the price of land, the buyer's income, spending devoted to housing were base and beneficiaries were selected in two broad categories good and medium economic in the Shiraz city.

2. The internal balance of beneficiaries' population: it is shown 3 different range of sampling groups (single unit villa, Twofamily condominium, one unit's ownership and other profit) and statistics of Engineering Organization of Fars and referred to the office during the last 10 years of research are cause 
that all data are place within 6 standard deviation (SD)(table6).

Table 6. Division of statistical social base on economic, type of housing and number of statistical sampling: author

\begin{tabular}{|l|l|l|}
\hline A1 group & $\begin{array}{l}\text { Medium economic of single } \\
\text { unit villa }\end{array}$ & 15 \\
\hline A2 group & $\begin{array}{l}\text { Medium economic of two- } \\
\text { family condominium }\end{array}$ & 30 \\
\hline A3 group & $\begin{array}{l}\text { Medium economic of one } \\
\text { unit's ownership and other } \\
\text { profit }\end{array}$ & 30 \\
\hline B1 group & $\begin{array}{l}\text { Good economic of single } \\
\text { unit villa }\end{array}$ & 30 \\
\hline B2 group & $\begin{array}{l}\text { good economic of two- } \\
\text { family condominium }\end{array}$ & 25 \\
\hline B3 group & $\begin{array}{l}\text { good economic of one unit's } \\
\text { ownership and other profit }\end{array}$ & 25 \\
\hline
\end{tabular}

1. For estimation of sample volume is used:

$$
n=\frac{s^{2} \times z^{2}}{d^{2}}
$$

$\mathrm{S}^{2}$ Variance research tool 729 in ideal condition it is $1 / 96$.

Z Significant level in $95 \%$ that the result of

d The difference between socity from sample, 4 from maximum score.

The resulting fraction (sample volume) $n=175$

In this study there were 10 exam drops.

So the total sample volume in this stage is 165 person (because of enough and complete answer).

The important note is that these number of exam that is used for factor analysis calculation that is proven the adequacy of sample size after KMO test and Bartlett test.

According to there was not the standard questionnaire to determine the status of beneficiary participation in the design of housing, is used from the questionnaire to collect the required information. The questionnaire was developed in several stages and was calculated it's the validity and reliability. For a valid test, you should try that questions of test is a perfect example of the purpose and related content of study. Therefore, by referring to libraries, scientific centers and content analysis and literature of study and subsequent interviews with experts and traditional designers can proper and produce a tool for answerquestionnaire with pack question.

With notice to document library and evidence environmental the criteria are (Table 7):

1. People's understanding of the impact of participation in improving the quality of housing and incentives to generate interest

2. The necessity of the participation and results of the work outcome

3. The role of the architect and his administration and value and price that other parties to pay attention them.

4. Owner satisfaction of participation

5. Participation feedback of social and cultural (efficiency and sustainable development)

6. Suitable admission for participation

7. The beneficiary behavior from designer when participating

8. The effect of situation and enough time for participation

Table 7. Objective-content: This table measures the scope and the limits of each of the variables and objectives in proportion to content (categories) and determines their limits.

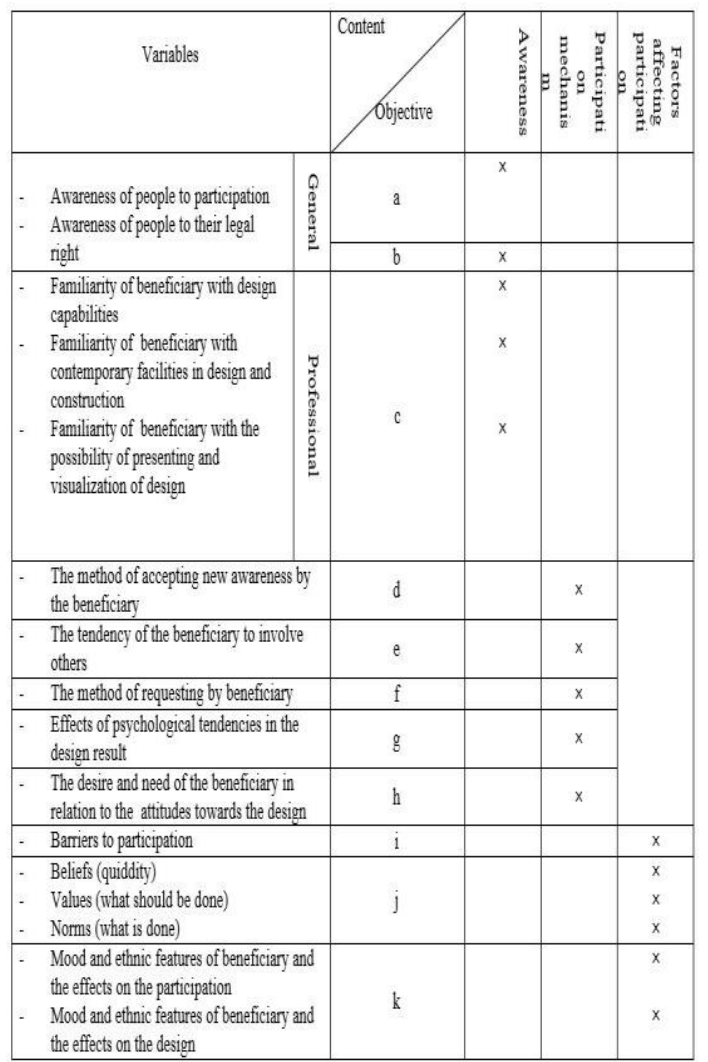

To check the questions of this study were used descriptive statistics, Pearson correlation coefficient, analysis of variance and multiple regressions analyzes. In descriptive statistics were used frequency tables and histograms. In addition, the mean-variance, standard deviation was calculated for each variable. 


\section{Conclusion}

Understanding the goal and investigating them, some variable are extracted from them that is basis for closed questions. These variables are as follows:

Public awareness to participate; b. public awareness of legal rights; c. Beneficiary awareness about designer capabilities; d. Beneficiary awareness of contemporary possibilities to design and production e. beneficiary Awareness of the features and design visualization; f. How Beneficiary admit new Awareness; g. willingness of beneficiary to participate with other h. how to say desires; i. psychological actions and effect on result of design; $j$. The desire and needs of beneficiary in relation to the kind of designer behavior; k. Barriers of participation; 1: Beliefs (nature) - values (what to do) - norms (what is done) m. behavior and ethnic characteristics of the beneficiary and effects on the participation.

First hypothesis: "Consultation between beneficiary and his family members about hosing design cause in knowing and understanding to housing space."

Second hypothesis: "Interaction of all family members in housing design, solved the Problems and abnormalities among family in term of knowing and expectation, and will be effective in knowing the areas and privacy of house."

Third hypothesis: participation of Operator Company and beneficiary in forming Residential space, is a factor of creating real space Beauty (Timely and efficient), adapting with space needs, and will prevent ineffective space and inconsistent with desires, needs and culture of users.

Forth hypothesis: Designer with a participatory approach in the design, not only can creates appropriate strategy to understand the real needs and necessary demands of employers, but also has enough skills to changing this desires to body.

Fifth hypothesis: "Designer with acquired experience in different interactions can learn useful strategy of architecture skills for changing and adjusting inappropriate expectations and desires of beneficiary, we use of regression analysis".

Sixth hypothesis: Designer can improve the quality of projects by acquiring experience of analyzing and comparing different beneficiaries in terms of time and space.

Seventh hypothesis: "Collaboration of population in the participatory design, leading to the promotion of culture and interactive climate and tolerance of dissenting views".

\section{References}

1. Alavi Tabar, A. R. (2003). A Model of Citizen's Participation in Urban Governance ( $2^{\text {nd }}$ Ed.). National Organization of Municipalities, Tehran.

2. Carlo, G. (2005). Architecture's public, in Blundel P., Petrescu D., Till J.,Architecture and Participation, Spon Press, London:3-22.

3. Eslami, G. M. (2001). The Process of Internal Production and Development. Fine Arts Journal, No. 10.

4. Ghaffari, Gh. R. (2000)" explain the affecting social and cultural factors for the organized socio-economic involvement", Thesis of Social Sciences University, Tehran, Iran.

5. Habibi, M. \& Saidi Rezvani, H. (2005). Participatory Urban Development, Theoretical Exploration of Situation in Iran, Fine Arts Journal, No. 24.

6. Hersey, P \&Blonckiard, K.(1988) Management of organizational Behaviour: utilizing Human Resources, Engle wood cliffs, newjersey.

7. Ismaili A. (1999). Presenting Demands of People in the Process of Reconstruction and Planning of City of Bam. Islamic Revolution Housing Foundation, Tehran.

8. Ismaili, A.(2005) " the presentation of the people's demands in the reconstruction and planning process of the Bam city", Islamic Revolution Housing Foundation, Tehran.

9. Kamel Nia, H. (2008). Architecture and Patterns of Collective Design, Doctoral Dissertation in Architecture, Faculty of Fine Arts, University of Tehran.

10. Mac Logan, P. \& Christonel, (1997). The Participation Age ( $2^{\text {nd }}$ Ed.).(Mostafa Eslamieh, Trans.). The Cultural Research Bureau, Tehran.

11. Mack Legan, P. \& Krystunel. (1997)," Partnership Age" (Second Edition) (translated by Mustafa Islamiya 1999), the Cultural Research Bureau, Tehran.

12. Mahmoudi A. S. (2005). Educational Papers. Publications of Negahe Emrooz, Tehran.

13. Mahmoudi, A. S. (2005) "The set of the education essays", publishing by Nashr-eNegah-e-Emroz, Tehran.

14. Maslow. (1367). Motivation And Personality, (Ahmad Rezavani, Trans.). Cultural Deputy of Astan Ghods, Mashhad.

15. Rahnavard, F. (1385), "point of view's participate", Institute of education and researching Management \& Planning, Tehran.

16. Rahnavard, F. (2006). Participation Approach. Higher Institute of Education and Research. Management and Planning, Tehran.

17. Razavi, Z.. (2005) "initiative of the people in decision-making, construction and 
reconstruction of Bam \& Baravat cities", the Interior Ministry, Tehran.

18. Rezaei, M.A. AS. (2002) Housing in Islam, Mehr Amir, Qom.se

19. Salama,A.(1995) Environmental Evaluation, jurnal of Architecturval Reseavch. AL AZHAR UNIVERSITY.

20. Salama A\& O'Reilly M.W\& Noschis K.(2005)Architectural Today:Cross-Cultural Education Comportements and authors.

Perspectives,

21. Sanoff, H. (2000) Community Participation Methods in Design and Planning. New York, John Wiley \& Sons, Inc.

22. Till, J.(2005) The negation of hope, in Blundel P. Petrescu D.

23. Tosi, M. A. (1991)," participation in management and ownership" (Fourth Edition), The training centre of Administration Mamegment, Tehran. 